\title{
Spatial modeling of limnological parameters in a solar saltwork of northeastern Brazil
}

\author{
Modelagem espacial de parâmetros limnológicos em uma salina solar \\ no nordeste do Brasil
}

Diógenes Félix da Silva Costa ${ }^{1.2}$, José Etham de Lucena Barbosa ${ }^{3}$,

Amadeu Mortágua Velho de Maia Soares ${ }^{2}$, Ana Isabel Lilleb $\varnothing^{2}$ and Renato de Medeiros Rocha ${ }^{1}$

${ }^{1}$ Department of Geography, Federal University of Rio Grande do Norte - UFRN, Campus de Caicó,

Rua Joaquim Gregório, s/n, Penedo, CEP 59300-000, Caicó, RN, Brazil

e-mail: diogenes.geo@gmail.com; renatocaico@yahoo.com.br

${ }^{2}$ Department of Biology, Centre for Environmental and Marine Studies - CESAM, University of Aveiro - UA,

Campus de Santiago, 3810-193 Aveiro, Portugal

e-mail: lillebo@ua.pt; asoares@ua.pt

${ }^{3}$ Department of Biology, State University of Paraíba - UEPB, Av. das Baraúnas, 351, Bodocongó, CEP 58100-001, Campina Grande, PB, Brazil

e-mail: ethambarbosa@hotmail.com

\begin{abstract}
Aim: In this research, we aimed to model limnological parameters in the Salina Unidos (Macau-Brazil) using GIS technology. We hypothesized that in solar saltworks, the geochemical characteristics of the brines (i.e. the strong solution of salts) vary considerably through the salt ponds circuit, in which drastic changes can damage the entire salt production. Methods: Geochemical parameters were monitored in seven sampling points distributed along the salt ponds circuit, during a complete cycle of salt production, i.e., from January to December 2007. The open source software Spring 5.1.6 was used to build, store, analyze and model the spatial distribution of the parameters. Results: We identified a spatial gradient of the salinity and temperature, with values increasing from evaporation ponds to concentration ponds, showing a relationship with the salt production. The parameters, depth, dissolved oxygen concentrations and total dissolved reactive phosphorus showed a decrease from the evaporation ponds towards the concentration ponds. Among the dissolved inorganic nitrogen forms analyzed $\left(\mathrm{NH}_{3}^{-}\right.$, $\mathrm{NO}_{2}{ }^{-}$and $\mathrm{NO}_{3}^{-}$), nitrate was the predominant, namely in the concentration ponds, where it reached the highest concentrations. The concentration of chlorophyll $a$ was higher in the initial and intermediate evaporation ponds, showing a distinct dynamics of in relation to other environmental variables. Conclusions: The increased concentration of the analyzed limnological parameters, from the evaporation ponds towards the concentration ponds, evidenced a heterogeneous distribution varying significantly with season. The geochemical spatialization of brine, as illustrated by GIS approach, is very important for the conservation of these environments because this spatial heterogeneity can provide a high diversity of habitat types. This spatial analysis proved to be a practical tool for an adequate management of solar saltworks considering the environmental (ecosystem) and the socio-economic aspects.
\end{abstract}

Keywords: salt production; water quality; management; GIS; Brazil.

Resumo: Objetivo: O objetivo deste trabalho é analisar os parâmetros limnológicas da Salina Unidos (Macau - Brasil) através do uso de tecnologia SIG. Nossa hipótese é que nas salinas solares, as características geoquímicas das salmouras podem variar consideravelmente através dos evaporadores de sal, onde uma alteração drástica no processo pode danificar toda a produção de sal. Métodos: Foram monitorados os parâmetros geoquímicos em sete pontos de amostragem distribuídos no circuito da Salina Unidos 
(Macau-Brasil), durante um ciclo de produção completa, de janeiro a dezembro de 2007. Foi utilizado o software livre Spring 5.1.6 para construir, armazenar, analisar e modelar a distribuição espacial dos parâmetros. Resultados: Um gradiente de salinidade e gradientes de temperatura, com valores que aumentam da zona de evaporação até a zona de concentração mostrando uma relação com a produção de sal. A profundidade, o oxigênio dissolvido e concentraçóes de fósforo inorgânico dissolvido mostraram uma diminuição da zona de evaporação até a zona de concentração. Para as formas de nitrogênio inorgânico dissolvido analisadas $\left(\mathrm{NH}_{3}^{-}, \mathrm{NO}_{2}^{-}\right.$e $\left.\mathrm{NO}_{3}^{-}\right)$, o nitrato foi o predominante, nomeadamente nas zonas de concentração, onde foram determinadas as concentraçóes mais elevadas. As concentraçóes de clorofila a foram mais altas na zona de evaporação inicial e intermediária, observando uma dinâmica distinta destes parâmetros em relação às outras variáveis ambientais. Conclusóes: Foi constatado o aumento da concentração dos parâmetros limnológicos analisados da zona de evaporação até a zona de concentração, mostrando uma distribuiçáo sazonal heterogênea e significativamente diferente. Esta segregação geoquímica gerada pela abordagem SIG na salmoura é muito importante para conservação destes ambientes, porque a heterogeneidade espacial pode fornecer uma diversidade alta de tipos de hábitat. A análise espacial tornou-se uma ferramenta prática o gerenciamento ao nível ambiental (ecossistema) como ao nível sócio-econômico.

Palavras-chave: produção de sal; qualidade da água; gerenciamento; SIG; Brasil.

\section{Introduction}

Multi-pond solar saltworks provide a wide range of environments characterized by an increasing salinity, along the salt production circuit, that varies from seawater levels up to sodium chloride saturation and sometimes even above saturation (Rodríguez-Valera, 1988; Javor, 1989). As water evaporates and salinity increases, the remaining water is pumped or flow by gravity to the following pond, so that salinity in each specific pond, along the circuit, is kept within narrow limits, i.e., basically constant. Each pond can thus be considered at chemical equilibrium, meaning that it is characterize by a specific habitat, to which a well-adapted and established community can be associated (Pedrós-Alió et al., 2000).

Salters are a specific type of coastal wetland's characterized by the permanent flooding of $90 \%$ of the area with brine for salt production. This integrated coastal ecosystem is specially designed according characteristics of the area (e.g. geomorphology, climate, tides flux); they are unique in terms of their architecture, and by combining their production process with the conservation of the coastal biodiversity (e.g. phyto and zooplankton, fishes, birds) (Korovessis \& Lekkas, 2009; López et al., 2010).

Worldwide saltworks can vary greatly in terms of the concentrations of inorganic nutrients and of the brines (the solution of salts). These variations might depend on geographical location, season and management practices, among other factors (Oren, 2000). Although these systems have been extensively studied in many geographic locations, few have attempted developing methods and techniques able to assist on brine management (Davis, 2000, 2009). The nutrient concentrations within a single pond can also vary considerably even within a few days, as shown in the study by Joint et al. (2002) in the saltworks of Santa Pola, (Alicante, Spain). Nutrients (nitrogen and/or phosphorus) are sometimes added as fertilizers to enhance the development of benthic microbial mats or planktonic communities of light-absorbing microorganisms (Oren, 2009).

The study on the relation between the biological communities and the salt production cycle, is not of purely academic interest only, in fact it is related and influences the saltwork management: the benthic cyanobacterial mats that develop in saltwork ponds of intermediate salinity effectively seal the bottom of these ponds preventing the leakage of the brine (Oren, 2009). Also, the importance on determining and analyzing the nutrient dynamics in the salt ponds along the salt production cycle is due to their high potential for developing eutrophication. Under specific conditions, namely lack of inorganic nutrients (nitrogen, phosphorus), unicellular Cyanobacteria that develop in these mats and in the brine might produce massive amounts of polysaccharide biofilm that unfavorably affects the salt production process; In this conditions the photosynthetically fixed carbon is released in the form of these extracellular polysaccharides (Roux, 1996). These organisms might also develop in the saltwork overlying water in some saltwork systems, where massive biofilm formation can negatively affect the salt production process (Davis \& Giordano, 1995/1996). 
Numerous techniques for temporal and spatial analysis have been applied in order to identify the different habitats that characterize these ecosystems (Kremen, 1992; Carleton et al., 1996; Dufrene \& Legendre, 1997; Wetzel \& Likens, 2000; Murtaugh \& Pooler, 2006; López et al., 2010). Conservation and management of these ecosystems call for the development of integrated methods, allowing for understanding and assessing habitats and for determining nutrients availability in each pond (Possingham et al., 2001; Ortega et al., 2004). The need to develop and improve methods and tools for controlling and preserving this type of wetland is a priority objective for managers and decision makers of salt enterprises, namely in Brazil (Medeiros Rocha et al., 2012).

There are several reasons for developing new GIS modelling approaches in spatial analyses on salt ponds. They can be used to assess the brine flow in the salt production cycle; to characterize the chemical properties of the brines; and the biological community, among other paramenters. This tool can be used to assess the conditions of the saltwork environment on the assumption that the presence or absence or even the fluctuations of these indicators, reflect changes taking place at various levels in the biogeochemical and biological cycles; thus the trends in ecological conditions and salt production over time can be monitored with this tool (Cairns
Junior et al., 1993; Noon et al., 1999; Wetzel \& Likens, 2000; Dale \& Beyeler, 2001).

This article proposes a stepwise statistical analyzes that was developed from the adaptation of a spatial modeling method, to analyze the distribution of limnological variables throughout the salt production cycle in solar saltworks. From the proposed analysis, managers can adapted the best strategy for the management of the saltwork, taking the maximum benefits of the biological systems associated to the salt ponds habitats. These biological communities are responsible for a considerable improvement in the salt production (e.g. reduction of the brine residence time in each pond, which represents a decrease in production time) (Davis, 2000, 2009). This approach is based on Geographical Information Systems - (GIS) gathered maps that clearly illustrate the distribution of the environmental parameters, allowing managers and decision markers identifying which saltwork sector showed high or low levels of the analyzed parameter (e.g. nutrients concentration).

\section{Material and Methods}

\subsection{Study site}

This research took place in a solar saltwork located in the Brazilian semi-arid shoreline (Figure 1A), Salina Unidos, Macau municipality,

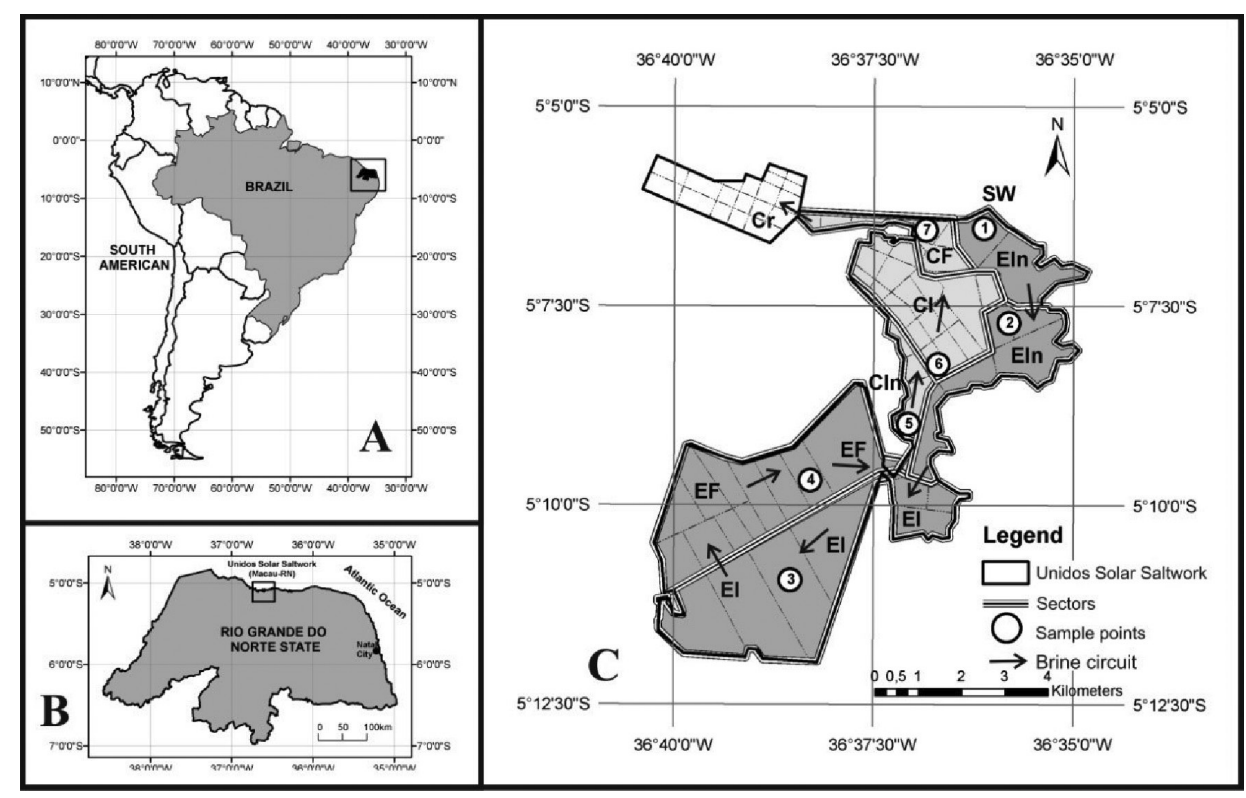

Figure 1. Map of the Salina Unidos, the ponds sampled, the direction of water/brine flow (from low to high salinity). Differentiation of the various types of ponds: Seawater entry pond (SW); Evaporation Zone (Initial - Ein, Intermediate - EI and Final - EF); Concentration Zone (Initial - Cin, Intermediate - CI and Final - CF) and crystallization ponds $(\mathrm{Cr})$. 
Rio Grande do Norte State (Figure 1B), delimited by the following coordinates: lat/long 01 - 5011'55.8"S/36040'19.0"W and lat/long 02 - 505'48.5”S/36 $34^{\circ} 44.5^{\prime \prime W}$ (Figure 1C). This saltwork occupies a flooded area of 4,663.7 hectares, is active all year-round, as almost all the Brazilian saltworks. There is however a lack of scientific data about its environmental conditions.

This study took place between January and December 2007. The first step was the characterization of the salt production cycle on the saltwork, by analyzing the brine management along the ponds. This saltwork presents the 'classical' production system (a sequence of evaporation and concentration ponds) divided into 07 zones, in which the brine flows to the following pond as soon as it reaches the specific pre- established salt saturation.

\subsection{Field sampling and sample analysis}

Following the description of the above mentioned brine circuit, each of the 07 defined zones correspond to a sampling pond. The objective was to characterize the physical, chemical and biological parameters in each zone of the salt production circuit. Samples were taken monthly in each pond, between January and December 2007 and, analyzed for 10 environmental variables (limnological parameters). Some of which were determined in situ, specifically salinity $\left(\mathrm{gL}^{-1}\right)$ - Portable Refractometer Fisher; water temperature $\left({ }^{\circ} \mathrm{C}\right)$ - digital thermometer; $\mathrm{pH}$ (portable digital pHmeter Hanna) and depth $(\mathrm{cm})$ - graduated rope with a weight. The concentration of dissolved oxygen was determined by Winkler method (Golterman et al., 1978); the concentration of dissolved inorganic nutrient (ammonium $-\mathrm{NH}_{3}$, nitrite $-\mathrm{NO}_{2}^{-}$, nitrate $-\mathrm{NO}_{3}^{-}$and total dissolved reactive phosphorous - TP) were determined by colorimeter method, following APHA (1992), Mackereth et al. (1978) and Rodier (1975) standardized methods; the concentration of chlorophyll- $a$ was determined by spectrophotometer, following the methodology described in APHA (1992).

\subsection{Data analysis}

Environmental variables were compared using the two-sample Kolmogorov-Smirnov test, since the data failed the Shapiro-Wilk normality test (Royston, 1982). To assess possible correlations between the environmental variables, cross-correlations were computed based on monthly averages (to obtain regular time series), and tested for significance. Environmental characterization of the sampling sites was done through a correlation-based Principal Component Analysis (PCA), considering the physical and chemical variables plus chlorophyll $a$ and pheophytyn, as proxy for phytoplankton, as well as depth (morphometric variable).

Although these parameters showed a significant annual variation, the aim of this research was too to test the GIS spatial modeling technique, as a support tool for analyzing the variation of the environmental parameters along the saltwork brine circuit. So, only the annual average value from each pond was used to build the model. For the development of this model using GIS, we used the software Spring 5.1.6 (Câmara et al., 1996), and followed 02 steps:

\subsection{Step 01 - Plotting of Sampling points using GIS}

In order to create the distribution model, the sampling points must have a relative distance taking into account the scale of the area, i.e., the pond; then the model allows for extrapolating these values for the entire pond. The distribution of these points was made considering the need to limit the different management zones in the saltwork. So, the sampling points were distributed to represent the entire pre-production system (from evaporation to concentration ponds). Considering the area of the entire saltwork and of the ponds, each sampling point had its value copied to 10 sub-points within the respective pond (this procedure was adopted for all variables analyzed). After defining this distribution, the file with the location of each point, and respective variable value, was exported (extension file type ".txt"), and a copy for each variable was generated. Afterwards, these files were imported with the GIS software, and transformed into a file with extension type ".spg", where each point was characterized by the following attributes: the value of the enviromental parameter and its georeferenced coordinate.

\subsection{Step $02-$ Geometric grids creation}

This second step consisted in the creation of two modeling grids, one triangular and other rectangular. For the triangular grid - TIN (Triangular Irregular Network), was chosen the type "Delaunay", with break line, being these simplified according with following references: tolerance level among lines $=16.0$, distance among isolines $=320.0$ and tolerance of break lines $=16.0$. 
Finally, the triangulation was defined with smaller edge $=3.2$ meters.

Afterwards, we created the rectangular grid based on numerical data of triangular grid (TIN), using a "linear" type interpolator. Considering the saltwork area $\left(46,630.000 \mathrm{~m}^{2}\right)$, the value of 50 meters was selected (scale admissible error $<20 \mathrm{~m}$, scale $1: 100,000)$ for axis $\mathrm{X}$ and $\mathrm{Y}$ of the pixel size $\left(250 \mathrm{~m}^{2}\right)$ on the image, resulting in grey tonality (optional color), with 32 bits. This final grid represents a series of mean values for each pixel located among sampling points, being attributed a tonality of grey level for these values.

\section{Results}

In accordance with the brine management, salinity showed a significant $\left(\mathrm{F}_{6,77}=246.17, \mathrm{p}<0.001\right.$, $\left.R^{2}=0.95\right)$ spatial variation along the salt production circuit, but no significant changes were find between sampling dates (time) $(\mathrm{p}>0.05)$. The salinity started with $32 \mathrm{gL}^{-1}$ on initial evaporation sector, and gradually increased throughout the salt production circuit, reaching $269 \mathrm{gL}^{-1}$ on the final concentration sector (Figures 2A, 3A). In terms of the saltwork
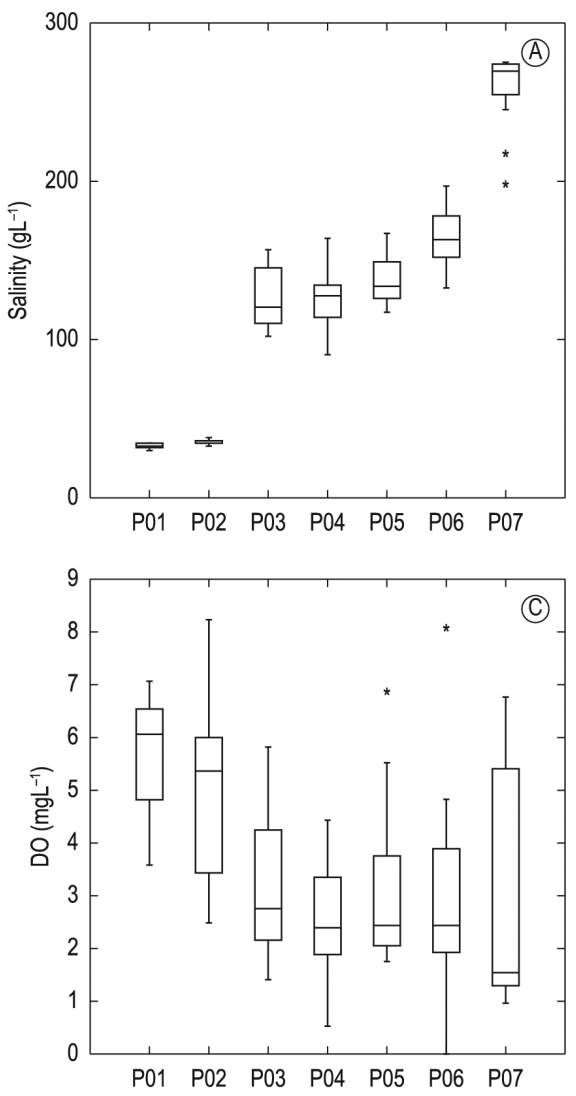

area subdivision, this variable was adopted as reference to divide the salt ponds into 02 zones: evaporation and concentration zones. Each of these zones was again subdivided into 03 sectors: initial, intermediate and final, as also done by other authors (e.g. Davis, 2000; Oren, 2009; López et al., 2010). In this sense, the Figures $2 \mathrm{~A}$ and $3 \mathrm{~A}$ shows a sector of initial evaporation, with salinity values between 32 and $50 \mathrm{gL}^{-1}$, intermediate from 50 to $100 \mathrm{gL}^{-1}$, and final from 100 to $150 \mathrm{gL}^{-1}$. Then, the initial sector of concentration zone began with salinity values between 100 and $150 \mathrm{gL}^{-1}$, the intermediate between 150 and $200 \mathrm{gL}^{-1}$, and the final ponds with brine saturation above $200 \mathrm{gL}^{-1}$. At this sector, the brine is directed to small crystallizer ponds for the final precipitation of sodium chloride.

Depth values of the salt ponds showed a 'typical' pattern for this type of man-made wetlands, where depth is controlled to ensure a specific volume related to salt production activity, i.e., following a progressive reduction from the evaporation to the concentration zone. In this sense, higher depth was observed at the initial evaporation pond $(210 \mathrm{~cm})$, and through the entire evaporation zone the depths
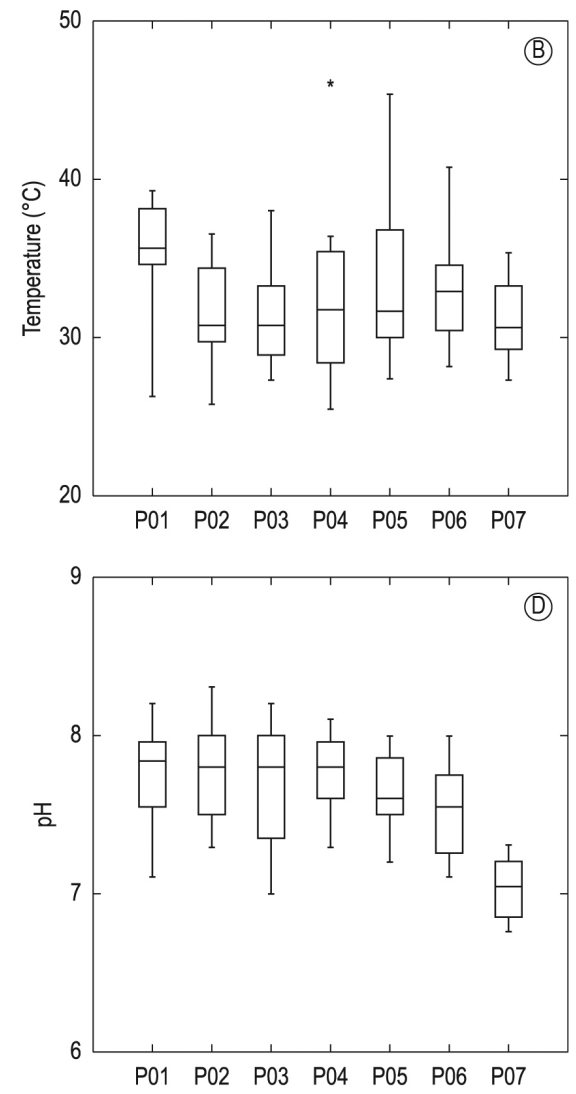

Figure 2. Spatial variation of salinity (A), temperature (B), $\mathrm{pH}(\mathrm{C})$ and dissolved oxygen (D) along the brine circuit on Salina Unidos. (*Extreme values). 

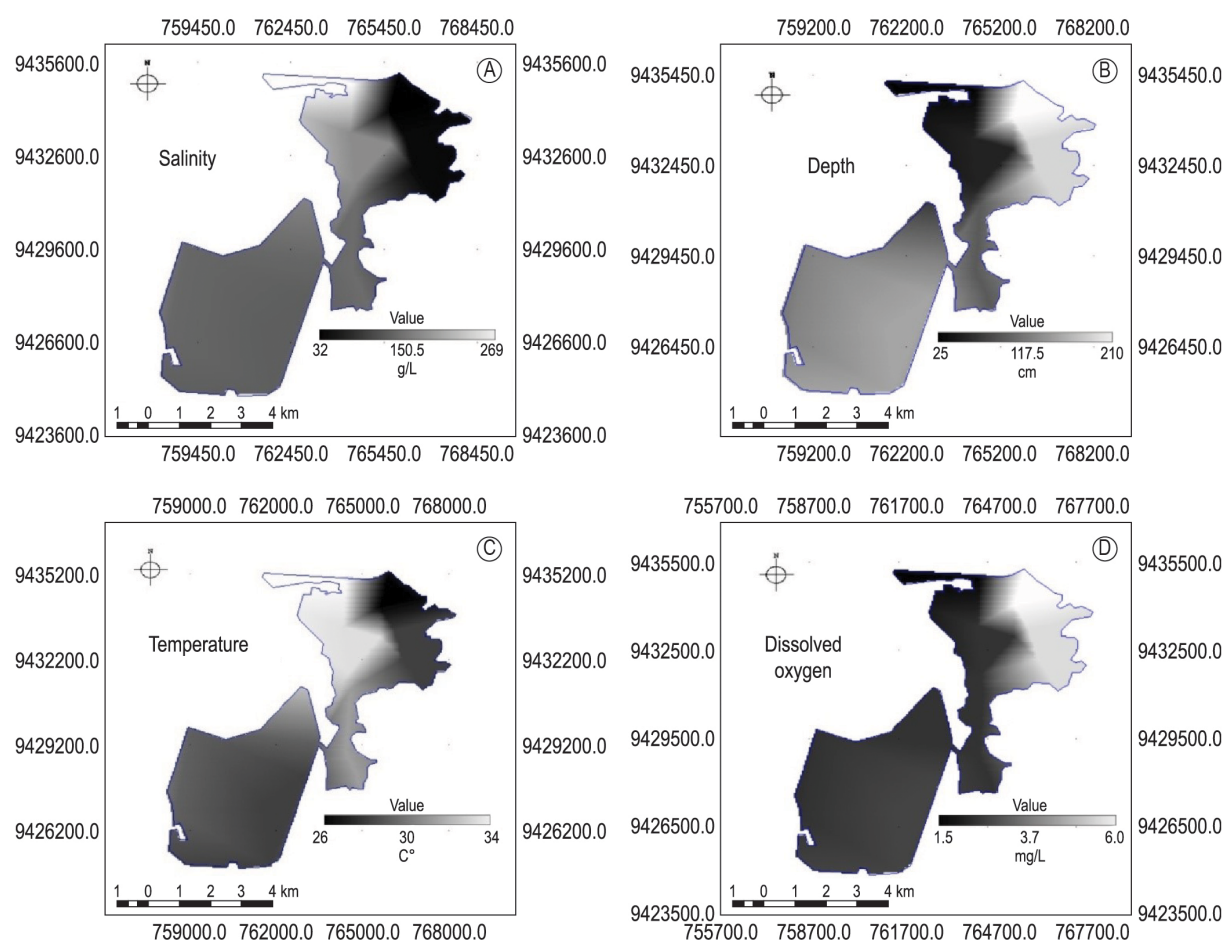

Figure 3. Spatial variation of salinity (A), depth (B), temperature (C) and dissolved oxygen (D) along the brine circuit on Unidos Solar Saltwork.

remained above $100 \mathrm{~cm}$. At the concentration zone, this value decreased gradually, reaching the lowest value in the final sector $(25 \mathrm{~cm})$. This morphometric parameter and the salinity were the first analyzed for the saltwork characterization as a system with differentiated habitats (Figure 3B).

In response to the salinity increase and depth reduction along the brine circuit, the water temperature presented a significant spatial variation $\left(\mathrm{F}_{11,72}=6.705, \mathrm{p}<0.001, R^{2}=0.50\right.$ ) (Figures 2B, $3 \mathrm{C}$ ), with mean values of $26^{\circ} \mathrm{C}$ in the initial sector of evaporation zone, and $30^{\circ} \mathrm{C}$ in final sector of this zone. In the concentration zone, temperature was allways above of $30^{\circ} \mathrm{C}$, and the highest value was recorded at the final sector of this zone $\left(34-39.6^{\circ} \mathrm{C}\right)$. The concentration of dissolved oxygen showed a significant spatial variation $\left(\mathrm{F}_{6,77}=6.429, \mathrm{p}<0.001\right.$, $R^{2}=0.33$ ) inversely proportional to salinity, but no significant temporal variation $(\mathrm{p}>0.05)$. Concentrations decreased gradually from the evaporation zone to the concentration (Figures 2C, $3 \mathrm{D})$, with higher values in the initial evaporation ponds $\left(6.0 \mathrm{mgL}^{-1}\right)$; intermediate values $\left(3.7 \mathrm{mgL}^{-1}\right)$ at the final sector of the evaporation zone and initial sector of the concentration zone; and reaching the lowest concentration $\left(1.5 \mathrm{mgL}^{-1}\right)$ in the final sector of the concentration zone, where the brine reaches the maximum salt saturation and is transferred to the crystallizers ponds (> $250 \mathrm{gL}^{-1}$ of $\mathrm{NaCl}$ ).

The analyzed brines from each salt pond showed alkaline characteristics, with spatial $\left(\mathrm{F}_{6,77}=9.852\right.$, $\left.\mathrm{p}<0.001, R^{2}=0.43\right)$ and temporal $\left(\mathrm{F}_{11,72}=4.732\right.$, $\left.\mathrm{p}<0.001, R^{2}=0.42\right)$ significant variation, where the average values (7.4) were found in initial sector, increasing to higher values (7.8) in intermediary sector of the evaporation zone. Then, these values decreased at the final sector of the evaporation zone and throughout the concentration zone, with minimum value (7.0) at the final sector of this last zone (Figures 2D, 5A).

Of all the dissolved inorganic forms of nitrogen analyzed in this study, nitrate presented the highest concentrations in all sampling ponds (Figures $4 \mathrm{C}, 5 \mathrm{D})$, varying spatial $\left(\mathrm{F}_{6,77}=3.534\right.$, $\left.\mathrm{p}<0.001, R^{2}=0.216\right)$ and temporally $\left(\mathrm{F}_{11,72}=3.084\right.$, $\mathrm{p}<0.001, R^{2}=0.32$ ), so that the spatial distribution along the saline showed a pattern of gradual increase from the evaporation zone to the concentration zone. The lowest values were recorded in the initial sector of evaporation zone $\left(128 \mu \mathrm{gL}^{-1}\right.$ - about 26 fold above the maximum value of nitrite and 11 of ammonium). The highest values $\left(202 \mu \mathrm{gL}^{-1}\right)$ were observed in the final sector of the evaporation zone (last evaporators of the salt production 
circuit). The average concentration of nitrate in the concentration zone was $165 \mu \mathrm{gL} \mathrm{L}^{-1}$.

The concentration of ammonium presented a heterogeneous spatial distribution, being significantly different between ponds $\left(\mathrm{F}_{6,77}=1.379\right.$, $\mathrm{p}>0.05, R^{2}=0.10$ ), with values ranging from 2.5 to $12 \mu \mathrm{gL}^{-1}$. In sequential order, the initial sector of the evaporation zone showed intermediate values for this variable $\left(7.2 \mu \mathrm{gL}^{-1}\right)$; followed by a reduction in ammonium concentration to the lowest values in the intermediate sector $\left(2.5 \mu \mathrm{gL}^{-1}\right)$, and an
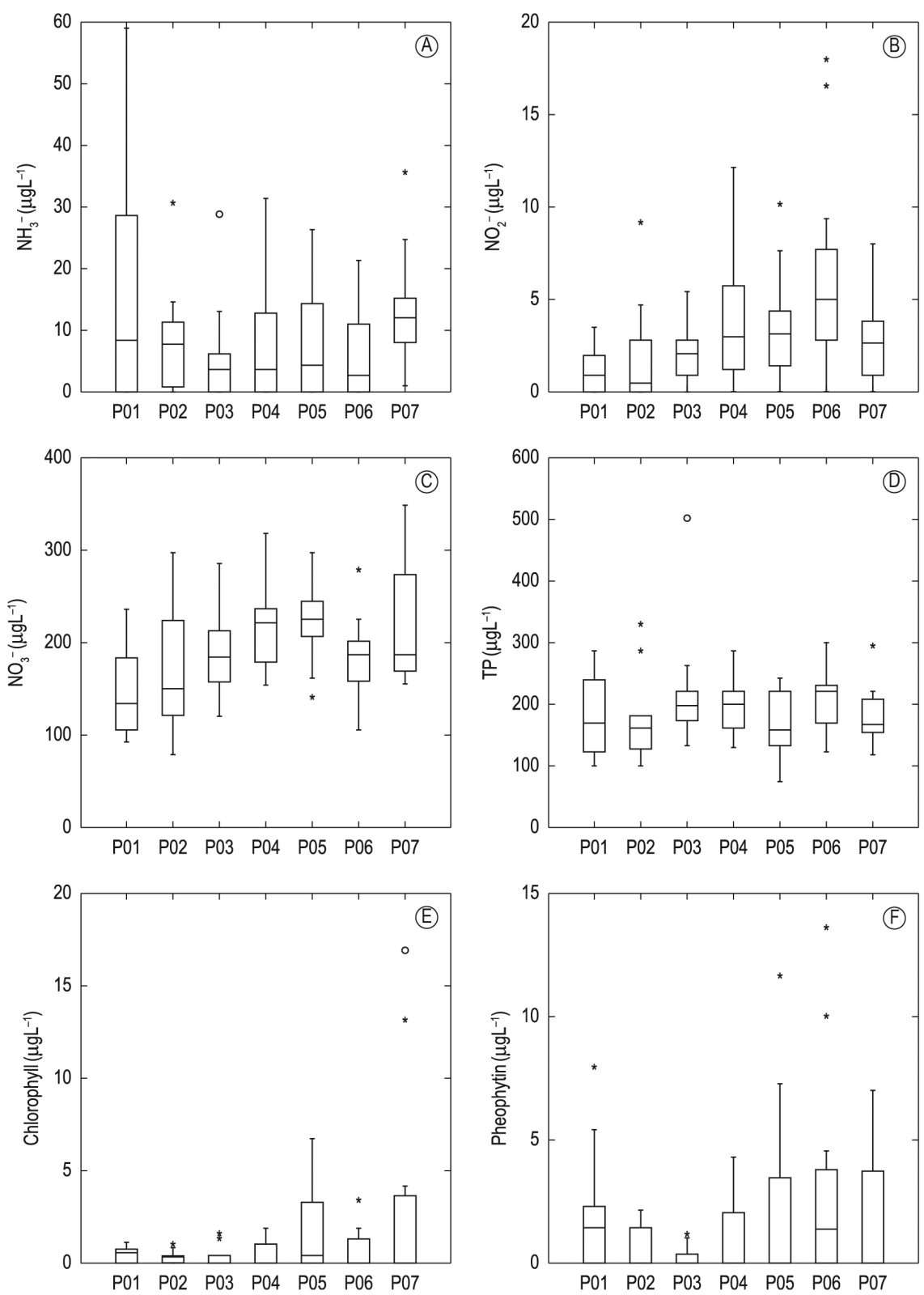

Figure 4. Concentration of dissolved inorganic nutrients (A - ammonium, B -nitrite, C-nitrate, D - total dissolved reactive phosphorus) and photosynthetic pigments (E - chlorophyll a; and F - Pheophytin) along the brine circuit in Salina Unidos. ( ${ }^{*}$ Extreme values; ${ }^{\circ}$ Outliers). 

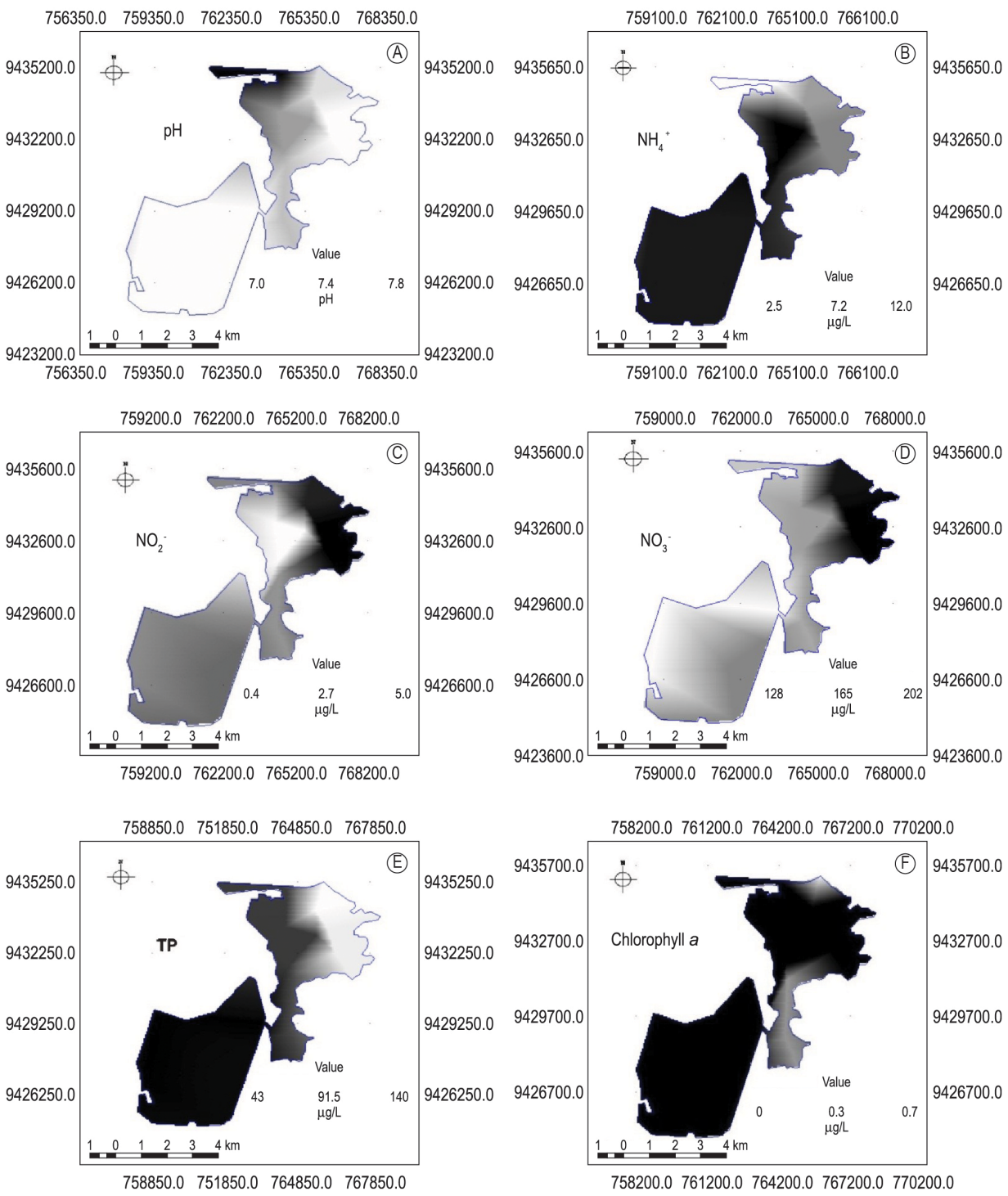

Figure 5. Variation of $\mathrm{pH}(\mathrm{A})$, nutrients $(\mathrm{B}$ - ammonium, $\mathrm{C}$ - nitrite, $\mathrm{D}$ - nitrate, $\mathrm{E}$ - total dissolved reactive phosphorus) and chlorophyll a (F) along the brine circuit in Salina Unidos.

starting from minimum values at the initial sector of the evaporation zone $\left(0.4 \mu \mathrm{gL}^{-1}\right)$, middle values in the intermediate sector of the evaporation zone $\left(2.7 \mu \mathrm{gL}^{-1}\right)$, reaching the highest values in the concentration ponds $\left(5.0 \mu \mathrm{gL}^{-1}\right)$. Finally, there was a reduction in the mean value on the concentration zone (maximum saturation of the brine) (Figures 4B, 5C).

Of all the nutrients, total dissolved reactive phosphorus showed higher values in the two saltworks zones, but with spatial and temporal significant differences (respectively: $\mathrm{p}<0.001$ and $\mathrm{p}<0.05)\left(\mathrm{F}_{11,72}=2.597, \mathrm{p}<0.001, R^{2}=0.28\right)$, with values varying between 43 and $140 \mu \mathrm{gL}^{-1}$. In terms of spatial distribution, higher values were observed in the initial sector of the evaporation zone, followed by a decrease in the intermediate sector, and a new increase $\left(<91.5 \mu \mathrm{gL}^{-1}\right)$ in the final sector of evaporation zone and throughout concentration zone (Figures 4D, 5E).

Regarding the photosynthetic pigments, the values of chlorophyll $a$ presented an average value of $0.3 \mu \mathrm{gL}^{-1}$; with values varying from below the method detection limit to $0.7 \mu \mathrm{gL}^{-1}$ (Figures $4 \mathrm{E}, 5 \mathrm{~F}$ ). Higher concentrations of chlorophyll a were found in initial and intermediate sectors of the evaporation zone; being spatially significantly different $\left(\mathrm{F}_{6,77}=2.336\right.$, $\left.\mathrm{p}<0.05, R^{2}=0.15\right)$ along the salt production circuit. Pheophytin presented an heterogeneous spatial distribution and a temporal significant variation $\left(\mathrm{F}_{11,72}=2.343, \mathrm{p}<0.05, R^{2}=0.26\right)$, that can be 
explained by the decomposition and accumulation of pigments along the brine circuit (Figure 4F).

In pond P1 (Figure 6A), the first axis of the component analysis explained $24.3 \%$ of total variance. It selects positively the salinity, dissolved oxygen and pheophytin $(\mathrm{p}<0.05)$. The second axis explained $18.3 \%$ of the variance and selects positively the nitrate, nitrite and temperature $(\mathrm{p}<0.05)$. For the P2 (Figure 6B), the first axis component explained $29.2 \%$ of total variance, and selects positively ammonium, nitrate, total dissolved reactive phosphorus and dissolved oxygen $(p<0.05)$. The second explained $19.4 \%$ of the variability and positively salinity, $\mathrm{pH}$, nitrite, chlorophyll $a$ and pheophytin $(\mathrm{p}<0.05)$. The pond P3 (Figure 6C) presents a first axis component explained $34.4 \%$ of total variance, and selects positively the photosynthetic pigments (chlorophyll $a$ and pheophytin) and $\mathrm{pH}(\mathrm{p}<0.05)$. The second explained $22.5 \%$ selected negatively $(\mathrm{p}<0.05)$ ammonium and dissolved oxygen, and positively $(\mathrm{p}<0.05)$ salinity, temperature, nitrate, nitrite and total dissolved reactive phosphorus. For the pond P4 (Figure 6D), the first axis component explained $26.9 \%$ of total variance, and selects negatively nitrate and salinity. Axis component $(20.3 \%)$ selected positively abiotic parameters ( $\mathrm{pH}$ and temperature), total dissolved reactive phosphorus and pheophytin $(\mathrm{p}<0.05)$. In pond P5 (Figure 6E), the first axis component explained $27.4 \%$ of total variance, and selects negatively nitrite but positively temperature, nitrate, total dissolved reactive phosphorus, chlorophyll $a$ and pheophytin. Axis component (23.6\%) selected negatively ammonium and dissolved oxygen, and positively salinity and $\mathrm{pH}(\mathrm{p}<0.05)$. The pond P6 (Figure 6F), the first axis component explained $31.2 \%$ of total variance, and selected negatively nitrite, $\mathrm{pH}$ and temperature and positively nitrate, dissolved oxygen, chlorophyll $a$ and pheophytin.
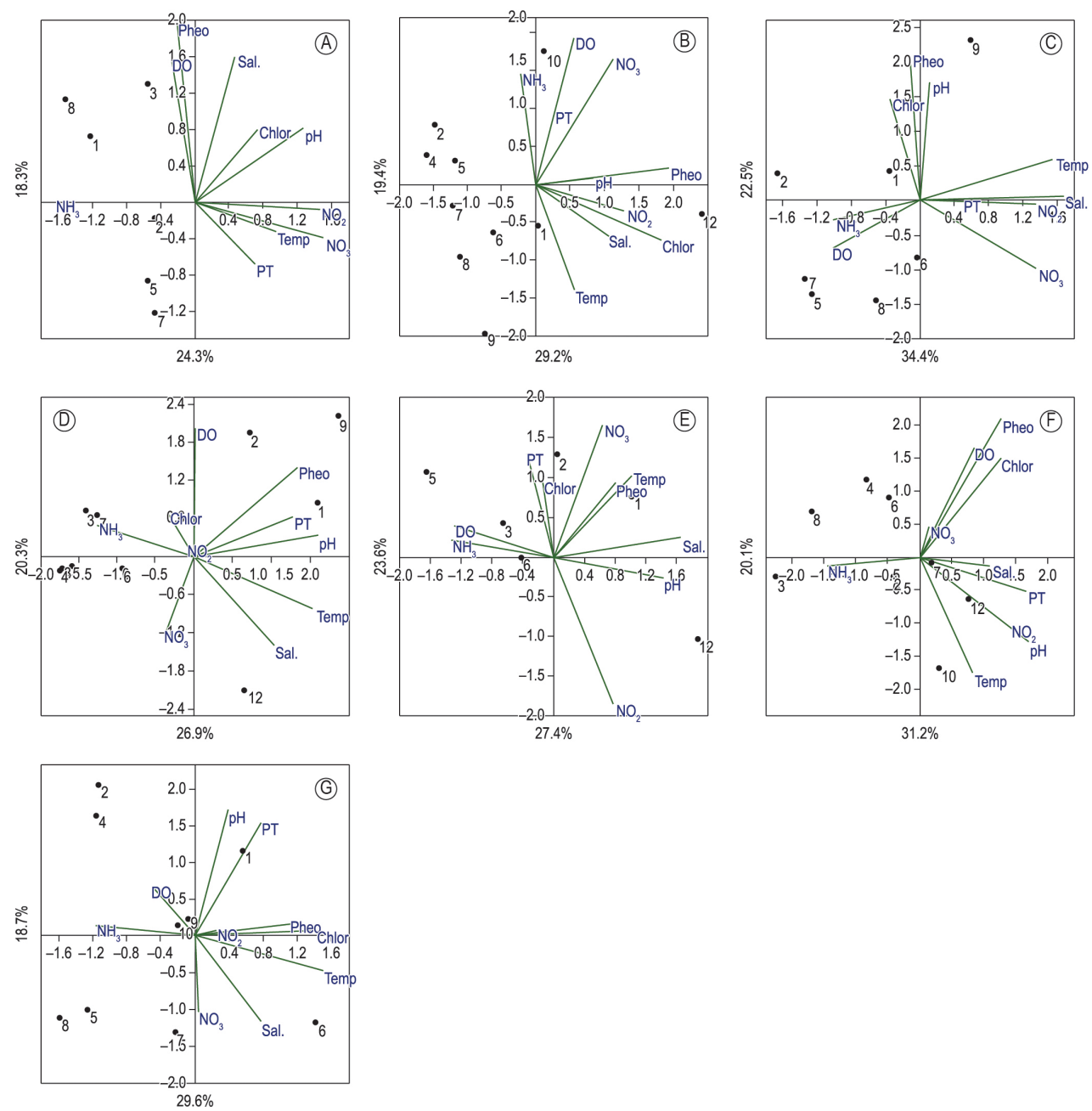

Figure 6. First two axes of the principal component analyses of limnological parameters per sampling site (A - P1, $\mathrm{B}-\mathrm{P} 2, \mathrm{C}-\mathrm{P} 3, \mathrm{D}-\mathrm{P} 4, \mathrm{E}-\mathrm{P} 5, \mathrm{~F}-\mathrm{P} 6$, and G-P7) and percentages of variance explained by the axes are given. 
The second Axis of the component analysis explained $20.1 \%$ of total variance, and selected negatively ammonium and positively salinity and total dissolved reactive phosphorus $(\mathrm{p}<0.05)$. Finally, in pond P7 (Figure 6G), the first axis component explained $29.6 \%$ of total variance, and selects negatively nitrate and salinity, and positively $\mathrm{pH}$ and total dissolved reactive phosphorus. Axis component (18.7\%) selected negatively ammonium and dissolved oxygen, and positively temperature, nitrite, chlorophyll $a$ and pheophytin ( $<<0.05)$.

\section{Discussion}

The salinity gradient was in agreement with the expected for the management of solar saltworks, where brine in salt ponds flows to the following pond along the salt production circuit in order to increase salinity. So, in the first evaporation ponds, salinity values corresponded to the sea/estuarine values, and the water remains until the salinity increase to $40 \mathrm{gL}^{-1}$, providing a marine habitat for many species. Following the production circuit, salinity progressively increases until reaching values above $200 \mathrm{gL}^{-1}$, providing a hypersaline habitat, very characteristic and unique among the more extreme worldwide for life development (Pedrós-Alió et al., 2000).

These results indicate that the initial evaporation ponds belong to a series of preliminary concentration ponds, which directly receive the seawater. This environment is characterized by the constant pumping of seawater (creating mechanical turbulence), warm temperature and high solar irradiance, together with nutrients that potentially accumulates in these ponds. The increase in temperature is clearly explained by the depth reduction in the salt pond and salt saturation of the brine, evidencing an association between light and temperature, as found in other studies (Abid et al., 2008; Khemakhem et al., 2010; López et al., 2010).

Regarding the concentration of dissolved oxygen along the production circuit, where salinity increases, and where the temperature also increases due to the higher caloric capacity of the brines, some of the initial ponds were supersaturated with oxygen, others at the end the production circuit had very low concentration due to the low solubility of oxygen at extremely high salinity and temperature (Pedrós-Alió et al., 2000).

The concentrations of dissolved inorganic nutrients were similar to those reported for other saltworks (e.g. Khemakhem et al., 2010;
López et al., 2010). Our assumption agrees with the hypothesis that when nutrients are sufficient, both temperature and light intensity can be determining factors on phytoplankton growth (Andersson et al., 1994). Nitrate concentrations reached the highest concentrations at the highest salinities, being the most abundant inorganic nutrient at the end of the circuit (Drira et al., 2008).

The source of the high concentrations of nitrate in the saltworks is often unclear, since autotrophic nitrification, which in less saline environments is responsible for the oxidation of ammonium from nitrite to nitrate, does not operate at salt concentrations above 100 to $150 \mathrm{gL}^{-1}$ (Oren, 1999, 2000). The determined concentrations of the dissolved inorganic nitrogen forms were always higher at intermediate and final ponds, showing a different pattern from dissolved inorganic reactive phosphorus. These differences between N-P concentrations were also reported in other saltworks (e.g. Wurtsbaugh \& Maciej Gliwicz, 2001; Dolapsakis et al., 2005; Khemakhem et al., 2010; López et al., 2010). Some of these high concentrations are generally characteristic of eutrophic to hypereutrophic aquatic systems (Javor, 1989; Aleya et al., 1994).

In most saltwork systems, nutrient concentration increases along with the increasing salinity. This may be due both to the evaporative concentration of the water and to bacterial activity. In addition, waterfowls are often found in great numbers near the evaporation ponds, and their droppings can also add to the nutrient pool of the saltworks (Oren, 2009; Khemakhem et al., 2010; López et al., 2010). The benthic microbial mats can also act as nutrient sinks as well as nutrient sources. Thus, the sharp increase in ammonium concentration in the Cabo Rojo (Puerto Rico) saltwork evaporation ponds during the wet season could be explained by the microbial degradation of nitrogen-containing osmolytes (glycine, betaine, ectoine, etc.) accumulated by the microbial community during the dry season (Casillas-Martinez et al., 2005).

Dissolved inorganic phosphorous concentrations showed opposite trends with salinity. There are large differences in nutrient concentration among different saltworks, to the point that saltworks can be classified as oligo-, meso- or eutrophic just as any other aquatic environment (Javor, 1989). These differences are reflected in planktonic chlorophyll $a$ content and in primary production, as well as in the predominance of autotrophic production in the plankton or in the benthos. In this regard, Salina 
Unidos can be assigned to the eutrophic saltwork types. The analyses of these parameters showed representative values in different ponds, being appropriate for monitoring the effectiveness of conservation and management strategies (Velasquez \& Hockey, 1991; Zacharias \& Roff, 2001). The use of modeling for spatialization with multifactorial statists approach presents important advantages by providing information on many physicochemical and biological characteristics of a system (i.e. gradients of the environmental conditions and to define the extent of similar environmental conditions).

\section{Conclusion}

As identified in the results, the salinity gradient is a key factor for the saltworks, from a functional point of view but also for the management of saltworks ponds. The spatial increase in salinity combined with the depth decrease determines the chemical and ecological processes in Salinas Unidos. This ecological segregation generated by brine flow along the salt production circuit is very important for conservation of these environments because spatial heterogeneity can provide a high diversity of habitat types (López et al., 2010).

About the benefits of the method that was applied, the Geographical Information System - GIS/SPRING 5.1.6 can be widely used as a tool to design management and monitoring programs in solar saltworks. In this way, a research priority will be to develop a product that can be easily used by the saltworks managers, through computation of in situ data. At the same time this product should be visually clear for an easy communication with and between the administratives of the enterprise and other stakeholders. An additional priority involves the development and testing of a method for the identification, mapping and analysis of different habitats in this complex wetland ecosystem.

The spatial analysis developed showed to be a practical tool to spatialize the distribution of physicochemical and biological properties of the saltwork system, and to highlight the major similarities and differences in the set of observations and variables considered. The stepwise procedure enable identifying potential habitats and analyze the variation of the biotic and abiotic parameters in coastal saltworks, that can be used to assess the conservation status of these systems from different perspectives and at different observation scales.

\section{Acknowledgements}

Wewould like to thank the personnel of Laboratory of Semi-Arid Ecology (LABESA/UFRN/CERES) for field and lab assistance. We are also indebted to CAPES (Coordenação de Aperfeiçoamento de Pessoal de Nível Superior), for the research fellowship granted to the first author (CAPES Proc. BEX. 5834/10-4). We would like to thank the company management of Unidos Salina (SALINOR S.A. Group) that put all the resources at disposal to carry out this research. We also would like to thank the anonymous reviewers for their very important and constructive comments and suggestions, which substantially improved the quality of the paper.

\section{References}

ABID, O., SELLAMI-KAMMOUN, A., AYADI, H., DRIRA, Z., BOUAIN, A. and ALEYA, L. Biochemical adaptation of phytoplankton to salinity and nutrient gradients in a coastal solar saltwork, Tunisia. Estuarine, Coastal and Shelf Science, 2008, 80(3), 391-400. http://dx.doi.org/10.1016/j. ecss.2008.09.007.

ALEYA, L., DESMOLLES, F., BONNET, M.P. and DEVAUX, J. The deterministic factors of the Microcystis aeruginosa blooms over a biyearly survey in hypereutrophic reservoir of Villerest (Roanne, France). Archiv für Hydrobiologie, 1994, 99, 1-26.

AMERICAN PUBLIC HEALTH ASSOCIATION APHA. Standard methods for the examination of water and wastewater. 18th ed. Washington, DC, 1992.

ANDERSSON, A., HAECKY, P. and HAGSTRÖM, A. Effect of temperature and light on the growth of micro- nano- and pico-plankton: impact on algal succession. Marine Biology, 1994, 120, 511-520. http://dx.doi.org/10.1007/BF00350071.

CAIRNS JUNIOR, J., MCCORMICK, P.V. and NIEDERLEHNER, B.R. A proposes framework for developing indicators of ecosystem health. Hydrobiologia, 1993, 263(1), 1-44. http://dx.doi. org/10.1007/BF00006084.

CÂMARA, G., SOUZA, R.C.M., FREITAS, U.M. and GARRIDO, J. Spring: Integrating remote sensing and GIS by object-oriented data modelling. Computers \& Graphics, 1996, 20(3), 395-403. http:// dx.doi.org/10.1016/0097-8493(96)00008-8.

CARLETON, T.J., STITT, R.H. and NIEPPOLA, J. Constrained indicator species analysis (COINSPAN): An extension of TWINSPAN. Journal of Vegetation Science, 1996, 7(1), 125-130. http://dx.doi. org/10.2307/3236425.

CASILLAS-MARTINEZ, L., GONZALEZ, M.L., FUENTES-FIGUEROA, Z., CASTRO, C.M., NIEVES-MENDEZ, D., HERNANDEZ, C., RAMIREZ, W., SYTSMA, R.E., PEREZ- 
JIMENEZ, J. and VISSCHER, P.T. Community structure, geochemical characteristics and mineralogy of a hypersaline microbial mat, Cabo Rojo, PR. Geomicrobiology Journal, 2005, 22(6), 269-281. http://dx.doi.org/10.1080/01490450500182672.

DALE, V.H. and BEYELER, S.C. Challenges in the development and use of ecological indicators. Ecological Indicators, 2001, 1(1), 3-10. http://dx.doi. org/10.1016/S1470-160X(01)00003-6.

DAVIS, J.S. Management of biological systems for continuously operated solar saltworks. Global NEST Journal, 2009, 11(1), 73-78.

DAVIS, J.S. Structure, function, and management of the biological system for seasonal solar saltworks. Global NEST Journal, 2000, 2(3), 217-226.

DAVIS, J.S. and GIORDANO, M. Biological and physical events involved in the origin, effects, and control of organic matter in solar saltworks. International Journal of Salt Lake Research, 1995/1996, 4(4), 335347. http://dx.doi.org/10.1007/BF01999117.

DOLAPSAKIS, N.P., TAFAS, T., ABATZOPOULOS, T.J., ZILLER, S. and ECONOMOU-AMILLI, A. Abundance and growth response of microalgae at Megalon Embolon solar saltworks in northern Greece: an aquaculture prospect. Journal of Applied Phycology, 2005, 17(1), 39-49. http://dx.doi. org/10.1007/s10811-005-5553-0.

DRIRA, Z., HAMZA, A., BELLHASEN, M., AYADI, H., BOUAIIN, A. and ALEYA, L. Dynamics of dinoflagellates and environmental factors during the summer in the Gulf of Gabes (Tunisia, Eastern Mediterranean Sea). Scientia Marina, 2008, 72, 59-71.

DUFRENE, M. and LEGENDRE, P. Species assemblages and indicator species: the need for a flexible asymmetrical approach. Ecological Monographs, 1997, 67, 345-366.

GOLTERMAN, H.L., CLYMO, R.S. and OHNSTAD, M.A. Methods for physical and chemical analysis of freshwaters. London: Blackweel Sci. Publ., 1978.

JAVOR, B.J. Hypersaline environments. Microbiology and biogeochemistry. New York: Springer Verlag, 1989.

JOINT, I., HENRIKSEN, P., GARDE, K. and RIEMANN, B. Primary production, nutrient assimilation and microzooplankton grazing along a hypersaline gradient. FEMS Microbiology Ecology, 2002, 39(3), 245-257. http://dx.doi. org/10.1111/j.1574-6941.2002.tb00927.x. PMid:19709204

KHEMAKHEM, H., ELLOUMI, J., MOUSSA, M., ALEYA, L. and AYADI, H. The concept of ecological succession applied to phytoplankton over four consecutive years in five ponds featuring a salinity gradient. Estuarine, Coastal and ShelfScience, 2010, 88(1), 33-44. http://dx.doi.org/10.1016/j. ecss.2010.02.019.
KOROVESSIS, N.A. and LEKKAS, T.D. Solar saltworks' wetland function. Global NEST Journal, 2009, 11(1), 49-57.

KREMEN, C. Assessing the indicators properties of species assemblages for natural areas monitoring. Ecological Applications, 1992, 2(2), 203-217. http:// dx.doi.org/10.2307/1941776.

LÓPEZ, E., AGUILERA, P.A., SCHMITZ, M.F., CASTRO, H. and PINEDA, F.D. Selection of ecological indicators for the conservation, management and monitoring of Mediterranean coastal salinas. Environmental Monitoring and Assessment, 2010, 166(1-4), 241-256. http://dx.doi. org/10.1007/s10661-009-0998-2. PMid:19479329

MACKERETH, F.J.H., HERON, J. and TALLING, J.F. Water analysis: some revised methods for limnologists. Ambleside Cumbria: Freshwater Biological Association Scientific Publication, 1978. no. 36.

MEDEIROS ROCHA, R., COSTA, D.F., LUCENAFILHO, M.A., BEZERRA, R.M., MEDEIROS, D.H., AZEVEDO-SILVA, A.M., ARAÚJO, C.N. and XAVIER-FILHO, L. Brazilian solar saltworks - ancient uses and future possibilities. Aquatic Biosystems, 2012, 8(1), 8. http://dx.doi. org/10.1186/2046-9063-8-8. PMid:22490329

MURTAUGH, P.A. and POOLER, P.S. Evaluating ecological indicators: lakes in the northeastern United States. Environmental Monitoring and Assessment, 2006, 119(1-3), 83-96. http://dx.doi.org/10.1007/ s10661-005-9011-x. PMid:16821100

NOON, B.R., SPIES, T.A. and RAPHAEL, M.G. Conceptual basis for designing and effectiveness monitoring program. In S.B. MULDER, B.R. NOON, T.A. SPIES, M.G. RAPHAEL, C.J. PALMER, A.R. OLSEN, G.H. REEVES and H.H. WELSH, eds. The strategy and design of the effectiveness monitoring program for the Northwest forest plan. Portland: US Department of Agriculture, 1999, pp. 21-48.

OREN, A. Bioenergetic aspects of halophilism. Microbiology and Molecular Biology Reviews, 1999, 63(2), 334-348. PMid:10357854.

OREN, A. Salts and brines. In B.A. WHITTON and M. POTTS, eds. Ecology of Cyanobacteria: their diversity in time and space. Dordrecht: Kluwer Academic Publishers, 2000, pp. 281-306.

OREN, A. Saltwork evaporation ponds as model systems for the study of primary production processes under hypersaline conditions. Aquatic Microbial Ecology, 2009, 56, 193-204. http://dx.doi.org/10.3354/ ame01297.

ORTEGA, M., VELASCO, J., MiLlÁN, A. and GUERRERO, C. An ecological integrity index for littoral wetlands in agricultural catchments of semiarid mediterranean regions. Environmental 
Management, 2004, 33(3), 412-430. http://dx.doi. org/10.1007/s00267-003-3059-6. PMid:15054671

PEDRÓS-ALIÓ, C., CALDERÓN-PAZ, J.I., MACLEAN, M.H., MEDINA, G., MARRASÉ, C., GASOL, J.M. and GUIXA-BOIXEREU, N. The microbial food web along salinity gradients. FEMS Microbiology Ecology, 2000, 32(2), 143-155. http://dx.doi.org/10.1016/S0168-6496(00)00025-8. PMid:10817867

POSSINGHAM, H.P., ANDELMAN, S.J., NOON, B.R., TROMBULAK, S. and PULLIAM, H.R. Making smart conservation decisions. In M.E. SOULÉ and G.H. ORIANS, eds. Conservation biology: Research priorities for the next decade. Washington: Island, 2001, pp. 225-244.

RODIER, J.L. Analyse de l'eau: eauxnaturelles, eaux residuals, eaux de mer. Paris: Dunod, 1975.

RODRÍGUEZ-VALERA, F. Characteristics and microbial ecology of hypersaline environments. In F. RODRÍGUEZ-VALERA, ed. Halophilic Bacteria. Boca Raton: CRC Press, 1988, pp. 3-30. vol. 1.

ROUX, J.M. Production of polysaccharide slime by microbial mats in the hypersaline environment of a Western Australian solar saltfield. Journal of Salt
Lake Research, 1996, 5(2), 103-130. http://dx.doi. org/10.1007/BF01995826.

ROYSTON, P. An extension of Shapiro and Wilk's W test for normality to large samples. Journal of Applied Statistics, 1982, 31(2), 115-124. http://dx.doi. org/10.2307/2347973.

VELASQUEZ, C.R. and HOCKEY, P.A.R. The importance of supratidal foraging habitats for waders at a south temperate estuary. Ardea, 1991, 80, 243-253.

WETZEL, R.G. and LIKENS, G.E. Limnological analysis. New York: Springer-Verlag, 2000.

WURTSBAUGH, W.A. and MACIEJ GLIWICZ, Z. Limnological control of brine shrimp population dynamics and cyst production in the Great Salt Lake, Utah. Hydrobiologia, 2001, 466(1-3), 119-132. http://dx.doi.org/10.1023/A:1014502510903.

ZACHARIAS, M.A. and ROFF, J.C. Use of focal species in marine conservation and management: A review and critique. Aquatic Conservation: Marine \& Freshwater Ecosystems, 2001, 11(1), 59-76. http:// dx.doi.org/10.1002/aqc.429.

Received: 21 February 2014 Accepted: 14 February 2015 